\title{
EFEKTIVITAS WAKTU KETERLAKSANAAN PERAN PERAWAT DI RUMAH SAKIT GIGI DAN MULUT UNIVERSITAS PADJADJARAN BERDASARKAN MATRIX EFEKTIFITAS WAKTU COVEY (2013)
}

\author{
Hesti Nuraeni $^{1}$, F.Sri Susilaningsih ${ }^{2}$, Ati Surya Mediawati ${ }^{2}$, Donny Juliandri Prihadi ${ }^{3}$ \\ 1 Rumah Sakit Gigi Dan Mulut, Universitas Padjadjaran, 40134 \\ 2 Fakultas Keperawatan, Universitas Padjadjaran, 45363 \\ ${ }^{3}$ Fakultas Perikanan dan IImu Kelautan, Univesitas Padjadjaran
}

Email : hesti.nuraeni@unpad.ac.id

\begin{abstract}
Berdasarkan telusur dokumen rekam medis pasien $(n=20)$ yang dilakukan pada bulan Januari 2019, pencatatan asuhan keperawatan yang meliputi tindakan pengkajian, diagnosis keperawatan, dan intervensi tidak teridentifikasi dalam dokumentasi rekam medis pasien. Berdasarkan wawancara dengan staf kepegawaian, didapatkan data masih banyak perawat yang sering datang terlambat dan terlihat kurang produktif pada saat jam kerja dengan mengobrol, bermain hp dan tidak berada di tempat. Tujuan penelitian: Efektivitas Keterlaksanaan Peran Perawat di Rumah Sakit Khusus Gigi dan Mulut. Metode: deskriptif dengan observasi menggunakan metode time and motion study Sampel dalam penelitian ini adalah seluruh aktifitas (dalam menit) yang dilakukan oleh 6 orang perawat selama shift kerja. Hasil : Berdasarkan efektivitas waktu, dinilai tidak efektif karena berada di kuadran IV (Tidak Penting- Tidak Mendesak) sebesar $46 \%$, menurut responden hal tersebut terutama pada saat pasien pre-operasi sehingga tidak banyak kegiatan yang dilakukan,dan waktu shift yang panjang selama 16 jam pada shift sore-malam sehingga lebih banyak aktivitas kegiatan pribadi. Aplikasi hasil :Keterlaksanaan peran perawat di RSGM Unpad secara efektivitas waktu berada di kuadran IV, yang berarti tidak efektif, maka diperlukan penetapan kompetensi perawat klinis agar peran perawat dilaksanakan dengan efektif.
\end{abstract}

Kata kunci : Efektivitas waktuPerawat,Peran, Rumah Sakit Gigi dan Mulut

\section{PENDAHULUAN}

Pelayanan keperawatan profesional dapat optimal jika perawat telah melaksanakan asuhan keperawatan sesuai dengan peran dan fungsinya. Namun fakta objektif yang terjadi pada saat ini, ada banyak perawat yang tidak melaksanakan peran dan fungsinya sesuai dengan kerangka tanggung jawabnya. Dalam melaksanakan peran dan fungsinya, perawat kerap melakukan peran dan fungsinya tersebut berdasarkan mother insting, rutinitas kegiatan, dan prosedur kerja dilakukan tanpa adanya pemahaman terhadap paradigma ilmu dan kiat keperawatan yang semestinya diaplikasikan ketika memberikan asuhan keperawatan kepada klien (Nursalam, 2015).

Sejalan meningkatnya kesadaran masyarakat terhadap pentingnya layanan kesehatan telah melahirkan daya paksa

\footnotetext{
*Corresponding Author :

Hesti Nuraini

Rumah Sakit Gigi dan Mulut

Universitas Padjajaran, Indonesia

Email : hesti.nuraini@unpad.ac.id
} 
yang besar terhadap ruang lingkup praktik perawat yang dituntut tidak hanya melakukan peran dan fungsinya terbatas pada pelayanan kesehatan di Rumah Sakit umum saja, tetapi juga telah meluas pada pelayanan kesehatan khusus. Hal tersebut terbukti dengan dengan berdirinya berbagai rumah sakit khusus, salah satunya adalah Rumah Sakit Gigi dan Mulut (RSGM). Pelayanan keperawatan di rumah sakit khusus diatur dalam berbagai regulasi diantaranya pada Peraturan Menteri Kesehatan No. 10 tahun 2015 tentang standar pelayanan keperawatan di rumah sakit khusus. PMK ini bertujuan untuk meningkatkan mutu pelayanan keperawatan di rumah sakit khusus dan rumah sakit umum yang memiliki pelayanan keperawatan kekhususan yang disusun atas dasar kompetensi dan kewenangan perawat. Meskipun di dalam regulasi tersebut belum tercantum standar pelayanan keperawatan pada Rumah Sakit Khusus Gigi dan Mulut, namun diharapkan konsep pelayanan keperawatan dalam ketentuan tersebut dapat menjadi acuan dan gambaran bagi pengembangan pelayanan keperawatan di rumah sakit khusus gigi dan mulut.

Berdasarkan data, mayoritas pasien yang menjalani bedah dan rawat inap di RSGM Unpad adalah pasien anak dengan diagnosa labioschizis dan palatoschizis.

\section{*Corresponding Author :}

Hesti Nuraini

Rumah Sakit Gigi dan Mulut

Universitas Padjajaran, Indonesia

Email : hesti.nuraini@unpad.ac.id
Pasien yang menjalani bedah dan harus di rawat inap memiliki permasalahan yang kompleks karena tidak hanya menyangkut hospitalisasi, anak dan orang tua dapat mengalami berbagai kejadian yang menurut beberapa penelitian ditunjukkan dengan pengalaman yang sangat traumatik dan penuh dengan stress. Berbagai perasaan yang sering muncul pada anak, yaitu cemas, marah, sedih, takut dan rasa bersalah. Seringkali mereka harus mengalami prosedur yang menimbulkan nyeri, kehilangan kemandirian dan berbagai hal yang tidak diketahuinya (Wong, 2009). Permasalahan tidak hanya muncul sebelum pembedahan, tetapi juga pasca pembedahan, antara lain nyeri, resiko infeksi luka, resiko, perdarahan, pemenuhan nutrisi, gangguan berbicara dan bahasa, serta resiko gangguan pendengaran sebagai perpanjangan efek dari infeksi luka yang meluas ke area levator veli palatini otot di sekitar tuba eustachius (Shahrokh, 2014).

Pasien yang mengalami permasalahan kesehatan gigi dan mulut tidak hanya membutuhkan tindakan medis dokter gigi untuk penyembuhan dan pemulihan kondisi sakit, namun membutuhkan tenaga kesehatan lainnya, salah satunya adalah perawat dalam memberikan asuhan holistik, melalui upaya asuhan keperawatan yang berbeda dengan 
pelayanan medis. Dalam upaya pemberian asuhan keperawatan gigi dan mulut, peran perawat harus sesuai dengan lingkup garapannya, yaitu menangani respons pasien selama sakit berupa respons fisik, sosio-kultural, psikologis dan spiritual klien terhadap penyakit atau masalah kesehatan gigi dan mulut lainnya. Sedangkan penanganan medis dokter gigi berfokus pada proses penyakit dan respon patofisiologis khusus yang cukup seragam dari satu klien ke klien yang lainnya. Diagnosis medis klien tetap sama selama ada proses penyakit, tetapi diagnosis keperawatan berubah sesuai perubahan respons klien (Kozier et al, 2011).

Berdasarkan telusur dokumen rekam medis pasien $(\mathrm{n}=20)$ yang dilakukan pada bulan Januari 2019, pencatatan asuhan keperawatan yang meliputi tindakan pengkajian, diagnosis keperawatan, dan intervensi tidak teridentifikasi dalam dokumentasi rekam medis pasien. Berdasarkan wawancara dengan staf kepegawaian, didapatkan data masih banyak perawat yang sering datang terlambat dan terlihat kurang produktif pada saat jam kerja dengan mengobrol, bermain hp dan tidak berada di tempat.

Pengelolaan waktu kerja perawat pelaksana dapat di identifikasi dari proporsi dan distribusi frekuensi waktu yang digunakan perawat untuk melakukan

\section{*Corresponding Author :}

Hesti Nuraini

Rumah Sakit Gigi dan Mulut

Universitas Padjajaran, Indonesia

Email : hesti.nuraini@unpad.ac.id aktivitas keperawatan dan nonkeperawatan dengan menggunakan metode matriks pengelolaan waktu. Covey (edisi revisi tahun 2013) dalam buku The Seven Habits of Highly Effective people memperkenalkan metode pengelolaan waktu berdasarkan tingkat urgensi (kegiatan yang memerlukan perhatian segera atau mendesak) dan tingkat kepentingan (kesesuaian dengan peran dan fungsi yang diemban).

Berdasarkan hasil penelusuran dokumen telusur dokumen, keterlaksanaan peran perawat sebagai pemberi asuhan keperawatan menjadi sulit untuk diidentifikasi karena tidak ada bukti dokumentasi (hard evidence). Berdasarkan wawancara dengan staf kepegawaian mengenai efektifitas kegiatan perawat tidak didapatkan data yang mendukung terkait efektifitas keterlaksanaan peran perawat di RSGM Unpad. Atas dasar itu, peneliti merasa perlu untuk melakukan penelitian mengenai Efektivitas Keterlaksanaan Peran Perawat di Rumah Sakit Khusus Gigi dan Mulut.

\section{METODE PENELITIAN}

Penelitian ini merupakan penelitian deskriptif dengan metode observasi time and motion study, merupakan metode pengamatan yang dilakukan secara terus menerus 
terhadap setiap jenis kegiatan perawat, dicatat secara terperinci serta dihitung lamanya watu untuk melakukan suatu tugas tertentu, satu pengamat mengamati satu subjek sampel selama jam kerja (1 shift).

Populasi dalam penelitian ini adalah seluruh aktivitas yang dilakukan oleh perawat pelaksana di RSGM Unpad sebanyak 6 orang perawat. Dalam fokus penelitian kuantitatif, sampel merupakan aktivitas waktu dalam satuan menit yang dibutuhkan untuk melakukan seluruh kegiatan oleh perawat pelaksana yang memenuhi kriteria inklusi dalam shift kerjanya masing-masing. Pengamatan dilakukan pada perawat pelaksana yang sudah ditentukan sebelumnya dan memenuhi kriteria inklusi sebagai objek dengan tehnik purposive sampling. Dengan kriteria sebagai berikut : Perawat pelaksana yang bekerja di ruangan $>3$ bulan bekerja, Pendidikan D3 Keperawatan dan S1 Keperawatan (Ners), Tidak sedang dalam cuti tugas belajar atau melahirkan. Untuk fokus penelitian kualitatif, sampel adalah seluruh staf RSGM Unpad yang berhubungan dengan klarifikasi hasil penelitian kuantitatif.

Instrumen yang digunakan adalah lembar observasi baku sehingga tidak lagi dilakukan uji validitas dan reabilitas.

\section{*Corresponding Author :}

Hesti Nuraini

Rumah Sakit Gigi dan Mulut

Universitas Padjajaran, Indonesia

Email : hesti.nuraini@unpad.ac.id
Instrumen yang digunakan adalah lembar observasi time and motion study yang disusun oleh llyas (2013). Peneliti menggunakan enumerator sebanyak 2 orang untuk mengobservasi kegiatan perawat di bedah sentral, sehingga dilakukan uji ekuivalensi enumerator menggunakan metode inter rater reliability dengan penilaian melalui prinsip Cohen's Kappa. Penilaian Cohen's Kappa dilakukan dengan menilai kesamaan/ kesepakatan antara dua orang observer,

Penelitian ini dilakukan di ruang Rawat Inap dan ruang Bedah Sentral RSGM Unpad dilakukan pada 6 orang perawat pelaksana di RSGM Unpad,setiap perawat diamati sebanyak dua kali pengamatan pada shift pagi dan shift sore-malam. Penelitian dilaksanakan pada bulan September November 2019.

\section{HASIL DAN PEMBAHASAN}

Berdasarkan tingkat pendidikan, responden yang memiliki pendidikan setingkat Diploma 3 keperawatan sebanyak 4 orang (67\%) dan S1 Keperawatan (Ners) sebanyak 2 orang (33\%). Berdasarkan lamanya waktu bekerja, 2 orang telah bekerja lebih dari 5 tahun $(33 \%)$ dan 4 orang telah bekerja kurang dari 5 tahun (67\%). Berdasarkan status kepegawaian, 4 orang berstatus 
sebagai pegawai tetap (BLU) unpad (67\%) dan 2 orang berstatus sebagai pegawai kontrak PT.M3 (33\%). Berdasarkan penempatan unit kerja perawat terdiri atas 1 orang (17\%) ditempatkan di Bedah Sentral dan 5 orang (83\%) ditempatkan di Instalasi rawat Inap, namun juga merangkap bekerja di instalasi gawat darurat, poli gigi umum dan bedah sentral bila diperlukan.

Dalam melaksanakan tugasnya, perawat di ruang rawat inap RSGM Unpad melakukan pergantian shift, yang terdiri atas shift pagi selama 8 jam (pukul 08.0016.00 WIB) dan shift sore-malam selama 16 jam (pukul 16.00-08.00 wib). Sedangkan perawat di bedah sentral tidak mengalami pergantian shift. Mereka setiap hari bekerja dari senin sampai jumat pukul 08.00 sampai 16.00 dengan jadwal kegiatan operasi pada hari senin, rabu, dan kamis.

Penelitian dimulai dari tanggal 23 September 2019 sampai 20 November 2019. Pasien dikategorikan berdasarkan tingkat ketergantungan pasien pada perawat, terdiri atas: minimal care, yang merupakan pasien yang membutuhkan pelayanan keperawatan langsung selama dua jam perhari; partial care, yaitu pasien yang membutuhkan pelayanan keperawatan langsung selama tiga jam perhari, dan total care, yaitu pasien yang membutuhkan pelayanan keperawatan

\section{*Corresponding Author :}

Hesti Nuraini

Rumah Sakit Gigi dan Mulut

Universitas Padjajaran, Indonesia

Email : hesti.nuraini@unpad.ac.id langsung selama empat sampai enam jam per hari. Berdasarkan jumlah pasien yang dirawat di RSGM Unpad selama proses pengamatan sebanyak 35 orang dengan klasifikasi pasien paling banyak ada pada kategori minimal care, yaitu 24 orang (69\%).

\section{Penggunaan Waktu Pelaksanaan Kegiatan Keperawatan menurut diagram Efektivitas Waktu Covey \\ Diagram efektivitas covey (2013)} dengan metode pengelolaan waktu berdasarkan tingkat urgensi (kegiatan yang memerlukan perhatian segera atau mendesak) dan tingkat kepentingan (kesesuaian dengan peran dan fungsi yang diemban), terdiri dari empat kuadran aktivitas. Kuadran I adalah segala aktivitas kegiatan langsung maupun kegiatan tidak langsung yang bersifat penting dan mendesak, seperti kegiatan pada keadaan krisis dan berkaitan dengan nyawa (keselamatan) pasien bila tidak segera ditangani, adanya masalah yang menekan, dan mengerjakan tugas pada akhir waktu. Kuadran II adalah segala aktivitas kegiatan langsung maupun tidak langsung yang penting namun tidak mendesak, yang mendukung kesembuhan pasien dan sesuai perencanaan. Kuadran III adalah segala aktivitas yang tidak penting dan mendesak yang tidak berkontribuasi terhadap kesembuhan pasien seperti interupsi dan selalu berselisih, kegiatan 
lebih banyak menulis/membuat laporan diluar asuhan keperawatan. Dan kuadran IV adalah segala kegiatan yang tampak sibuk, hanya terdapat waktu luang/melakukan hal sepele, banyak kegiatan rehat, menelepon (aktivitas menyenangkan).

Tingkat urgensi ditentukan oleh peneliti selama pengamatan langsung di lapangan serta klarifikasi langsung kepada responden mengenai kegiatan yang responden lakukan sehingga peneliti dapat mengambil kesimpulan terhadap kepentingan dan urgensi tindakan yang dilakukan responden untuk selanjutnya diklasifikasi kan sesuai dengan diagram efektivitas Covey. Berikut adalah distribusi efektifitas waktu pelaksanaan kegiatan keperawatan yang dilaksanakan oleh perawat di RSGM Unpad.

Tabel 1.1 Distribusi penggunaan waktu pelaksanaan kegiatan keperawatan menurut diagram efektivitas waktu covey pada shift pagi (8 jam)

\begin{tabular}{lcc}
\hline $\begin{array}{l}\text { Kategori Jenis } \\
\text { Kegiatan }\end{array}$ & Jumlah waktu (menit) \\
\hline $\begin{array}{l}\text { Kuadran I (Penting- } \\
\text { Mendesak) }\end{array}$ & 494 & \\
\hline $\begin{array}{l}\text { Kuadran II (Penting- } \\
\text { Tidak Mendesak) }\end{array}$ & 2221 \\
\hline $\begin{array}{l}\text { Kuadran III (Tidak } \\
\text { Penting-Mendesak) }\end{array}$ & 58 \\
\hline $\begin{array}{l}\text { Kuadran IV (Tidak } \\
\text { Penting-Tidak } \\
\text { Mendesak) }\end{array}$ & 211 \\
\hline Total & 914 & \\
& & \\
\end{tabular}

\section{*Corresponding Author :}

Hesti Nuraini

Rumah Sakit Gigi dan Mulut

Universitas Padjajaran, Indonesia

Email : hesti.nuraini@unpad.ac.id
Tabel 1.1 merupakan distribusi penggunaan waktu pelaksanaan kegiatan keperawatan menurut diagram efektivitas waktu covey pada shift pagi (8 jam), waktu kegiatan terbanyak ada pada kuadran II (Penting-Tidak Mendesak) didapat selama 2221 menit (58\%), maka kegiatan perawat pada shift pagi dapat dikategorikan efektif.

Pada shift pagi di dapatkan hasil kegiatan terbanyak pada kuadran II (penting-tidak mendesak) sebesar 58\% dari keseluruhan waktu pada shift pagi yang berarti kegiatan perawat dalam kategori efektif. Kegiatan yang dimasukkan dalam kuadran II merupakan kegiatan yang dilaksanakan perawat secara terencana, tidak tergesa-gesa dan berkaitan dengan asuhan pasien, seperti dokumentasi, melengkapi rekam medis, mengantar pasien ke bedah sentral, mengukur vital sign, injeksi obat, dan kegiatan lainnya sesuai rencana baik yang tertulis maupun disampaikan secara lisan melalui handover. Perawat membuat rencana asuhan sebagai rutinitas dan terkesan mengulang ulang dari perencanaan yang sebelumnya. Rencana asuhan seharusnya dibuat berdasarkan respons pasien pada saat pengkajian, sesuai yang di dalam American Nursing Assosiation (ANA) (2010), keperawatan adalah respon individu terhadap masalah kesehatan baik yang bersifat aktual maupun potensial. Maka yang menjadi fokus/ fenomena dalam keperawatan.

adalah respons individu. Respon ini berupa respon bio-psiko-sosio dan spiritual pasien terhadap masalah kesehatannya baik yang bersifat aktual maupun potensial. Respons individu inilah yang menjadi kajian di dalam keperawatan dan menjadi dasar dalam implementasi tindakan keperawatan.

Berdasar pengamatan peneliti selama observasi kegiatan, perawat di 
ruangan cenderung melakukan aktivitas rutin, misalnya pada jam tertentu perawat melakukan tindakan injeksi obat, mengukur tanda-tanda vital, menyiapkan air hangat untuk seka, skin test. pada malam hari perawat jarang memantau kondisi pasien di ruangan, perawat datang ke ruangan saat injeksi obat atau saat keluarga meminta pertolongan. Selain itu, kegiatan perawat duduk di nurse station ataupun mengobrol dengan petugas lain dengan topik umum atau menonton tv dan main Hp. Persiapan tindakan keperawatan sering dilakukan perawat pada pagi hari, menyiapkan obat injeksi dan persiapan alat yang akan digunakan residen untuk ganti verban. Kegiatan tidak langsung paling banyak adalah dokumentasi rekam medis dan melengkapi berkas rekam medis pasien, dikarenakan banyak lembar baru yang harus di tulis, tidak jarang perawat kurang fokus dalam pendokumentasian, perawat menuliskan dokumentasi sambil berbincang bincang sehingga waktu untuk menulis dokumentasi menjadi panjang, hal tersebut juga menjadikan waktu yang dimiliki perawat menjadi tidak efektif. Aktivitas atau kegiatan perawat yang efektif adalah aktivitas atau kegiatan yang dilakukan (kegiatan keperawatan langsung maupun tidak langsung) sesuai dengan apa yang direncanakan dan ketepatan dalam menentukan prioritas kerja sesuai dengan

\section{*Corresponding Author :}

Hesti Nuraini

Rumah Sakit Gigi dan Mulut Universitas Padjajaran, Indonesia Email : hesti.nuraini@unpad.ac.id peran, fungsi, kompetensi dan tanggung jawab sebagai perawat (Covey, 2013; Potter \& Perry, 2013).

Tabel 1.2 Distribusi penggunaan waktu pelaksanaan kegiatan keperawatan menurut diagram efektivitas waktu covey pada shift sore-malam (16 jam)

\begin{tabular}{|c|c|c|}
\hline Kategori Jenis Kegiatan & $\begin{array}{l}\text { Jumlah } \\
\text { waktu } \\
\text { (menit) }\end{array}$ & $\%$ \\
\hline Kuadran I (Penting-Mendesak) & 277 & 6 \\
\hline Kuadran II (Penting-Tidak Mendesak) & 1468 & 30 \\
\hline $\begin{array}{l}\text { Kuadran III (Tidak Penting- } \\
\text { Mendesak) }\end{array}$ & 0 & 0 \\
\hline $\begin{array}{l}\text { Kuadran IV (Tidak Penting-Tidak } \\
\text { Mendesak) }\end{array}$ & 3055 & 64 \\
\hline Total & 4800 & 100 \\
\hline
\end{tabular}

Tabel 1.2 merupakan distribusi penggunaan waktu pelaksanaan kegiatan keperawatan menurut diagram efektivitas waktu covey pada shift sore-malam. Waktu kegiatan terbanyak ada pada kuadran IV (Tidak Penting-Tidak Mendesak) didapat selama 3055 menit (64\%), maka kegiatan perawat pada shift sore-malam termasuk kategori tidak efektif. Menurut responden hal ini dikarenakan waktu kerja yang terlalu panjang, selama 16 jam dari pukul 16.00 sampai dengan pukul 08.00 pagi. meskipun perawat jaga hanya 1 orang dirasakan masih banyak waktu luang, terutama pada pasien baru pre-operasi, tidak banyak kegiatan yang dilakukan oleh perawat di 
ruangan hanya mengecek kelengkapan rekam medis dan persiapan operasi pasien, kesibukan hanya pada waktu tertentu saja, karena sebagian besar kegiatan seperti penerimaan pasien baru dan pemulangan pasien, intruksi dokter, antar jemput pasien dan pemberian obat lebih banyak pada shift pagi sedangkan pada shift sore-malam kegiatan yang dilakukan adalah meneruskan sesuai intruksi rencana kegiatan di shift pagi.

Tabel 1.3 Distribusi penggunaan waktu pelaksanaan kegiatan keperawatan menurut diagram efektivitas waktu covey selama 24 jam

\begin{tabular}{|c|c|c|}
\hline Kategori Jenis Kegiatan & Iaktu & $\%$ \\
\hline Kuadran I (Penting-Mendesak) & 771 & 9 \\
\hline Kuadran II (Penting-Tidak Mendesak) & 3689 & 43 \\
\hline Kuadran III (Tidak Penting-Mendesak) & 211 & 2 \\
\hline $\begin{array}{l}\text { Kuadran IV (Tidak Penting-Tidak } \\
\text { Mendesak) }\end{array}$ & 3969 & 46 \\
\hline Total & 8640 & 100 \\
\hline
\end{tabular}

Hasil penelitian pada tabel 1.3 diatas, kegiatan perawat menurut efektivitas waktu, didapatkan hasil berdasarkan distribusi waktu kegiatan secara keseluruhan (24 jam) didapatkan hasil dalam kategori tidak efektif (kuadran IV) sebesar $46 \%$. Sebagian besar waktu yang dihabiskan perawat berada dalam kuadran IV yang merupakan kategori kegiatan tidak penting dan tidak mendesak.
Maka dapat disimpulkan perawat dalam melaksanakan kegiatan masih belum efektif dalam penggunaan waktu.

Kurang efektifnya waktu yang digunakan perawat, disebabkan karena jumlah pasien yang tidak banyak, hanya 3 sampai 4 pasien setiap hari nya dan kategori ketergantung mayoritas berada pada level minimal care sebesar $69 \%$. Selain itu, pelaksanaan Pencegahan Pengendalian infeksi masih belum optimal dilaksanakan oleh perawat, perawat terlihat kurang peduli dengan keadaan sekitar yang kurang rapih dan bersih. Prosedur keselamatan pasien pun kadang terlupakan oleh perawat, pemasangan gelang keselamatan, prosedur keselamatan pasien sebelum kegiatan masih belum terlaksana dengan baik. Bila prosedur pencegahan infeksi dan keselamatan pasien dapat terlaksana, maka efektifitas waktu kerja perawat dapat lebih optimal.

\section{SIMPULAN}

Peran dan fungsi perawat di RSGM Unpad masih belum sesuai dengan domain keperawatan meskipun telah teridentifikasi pengkajian keperawatan dan catatan asuhan keperawatan dalam dokumentasi rekam medis, namun dalam pelaksanaan kegiatan berdasarkan kegiatan rutin dan dan tanggung jawab, belum berdasarkan rencana kegiatan berdasarkan respons pada saat pengkajian

\section{SARAN}

Penelitian ini diharapkan dapat memperkaya ilmu pengetahuan dalam bidang kesehatan khususnya Keperawatan gigi.

\footnotetext{
*Corresponding Author :

Hesti Nuraini

Rumah Sakit Gigi dan Mulut

Universitas Padjajaran, Indonesia

Email : hesti.nuraini@unpad.ac.id
} 


\section{DAFTAR PUSTAKA}

American Nurses Association (ANA).( 2010a). Nursing's social policy statement: The essence of the profession. Silver Spring, MD: Nursesbooks.org.

Covey,S. (2013). The Seven Habits of Highly Effective People. Jakarta. Bina Rupa Aksara

Ilyas Y, .(2013). Perencanaan SDM Rumah Sakit, Teori, Metoda dan Formula. Depok: Penerbit Fakultas Kesehatan Masyarakat Universitas Indonesia International council of nurses. (2013). Nursing Definitions. Retrivied from https://www. icn. ch/ nursingpolicy/nursing-definition

Kozier Barbara, Erb Glenora, Berman Audrey and Synder J.(2011). Fundamental Keperawatan : Konsep, Proses dan Praktik. EGC. Jakarta

Nursalam. (2015). Aplikasi dalam Praktek Keperawatan Profesional. Jakarta: Salemba Medika

Peraturan Menteri Kesehatan Nomor 10 tahun 2015 Tentang Standar Pelayanan Keperawatan Di Rumah Sakit Khusus

Potter, P.A., Perry, A.G., Stockert, P.A., Hall, A.M. (2013). Fundamentals of nursing. 8th ed.St. Louis, Missouri: Elsevier Mosby

\section{*Corresponding Author :}

Hesti Nuraini

Rumah Sakit Gigi dan Mulut Universitas Padjajaran, Indonesia Email : hesti.nuraini@unpad.ac.id
Shahrokh C Bagheri. (2014). Clinical review of oral and maxillofacial surgery. hal 463, Mosby Inc : Missouri

Undang-Undang Republik Indonesia Nomor 38 tahun 2014 tentang Keperawatan

Wong L.Donna. (2009). Pedoman Klinis Keperawatan Pediatrik. Jakarta:EGC 